KYIV-MOHYLA

HUMANITIES JOURNAL

KYIV-MOHYLA SCHOLARLY PEER-REVIEWED JOURNALS

One Hundred Years of the Ukrainian Liberation Struggle

Author(s): Serhiy Kvit

Source: Kyiv-Mohyla Humanities Journal 4 (2017): 145-152

Published by: National University of Kyiv-Mohyla Academy

http://kmhj.ukma.edu.ua/ 


\title{
One Hundred Years of the Ukrainian Liberation Struggle
}

\author{
Serhiy Kvit
}

\begin{abstract}
(2)
To understand historical processes, it is not nearly enough to take into account only objective distant social, political, and economic factors. We also need to pay attention to different wellestablished traditions, stereotypes and existing myths-archetypes, which unavoidably accompany and fill historical memory. Later, some of them are legalized by historiography or, better to say, by different conflicting historiographies. Such an unwritten tradition helps to understand social phenomena which came from somewhere and just exist by outlining dramatic differences of contemporary Ukrainian political culture, as opposed to a number of post-Soviet countries, in particular, Russia. It is especially interesting considering the global importance of the events happening in contemporary Ukraine. During World War I, Ukrainians were trying to create their independent state, as well as to fit it into the geopolitical context of that time. The defeat of the Liberation Struggle and all of Ukrainian history up to the collapse of the Soviet Union until today make us take a close look at historically remote events.
\end{abstract}

\section{How Many States did the Ukrainians Create through Their Liberation Struggle?}

Much has already been written about the tactfulness of the Ukrainian language, which uses affectionate diminutive forms in folklore even regarding its deadly enemies, calling them vorizhenky. In a similar manner, the concept of a "Liberation Struggle" (literally closer to the meanings of "competition" or "effort") has a substantial romantic implication, which, to some extent, poeticizes the attempts of Ukrainians to found and consolidate their state at the beginning of the 2oth century. This poetization pays attention to the process, rather than to the result, which has to be concrete. Accordingly, people who were fighting but did not reach the desirable result (those who were killed or defeated) become historical role-models, and so on; as if a new heroic folklore composition is being created. In the case of the Liberation Struggle of 1917-1920, not only national memory, but also the Ukrainian political tradition and historiography have recorded this unaccomplished fact of state formation with similar poeticized descriptions.

It is impossible even to calculate how many states Ukrainians created at that time since besides the Ukrainian People's Republic (1917-1920) with its capital in Kyiv, there were also the Western Ukrainian People's Republic (1918-1919) with its center in Lviv, and the Ukrainian State (1918) also with Kyiv as its capital. A large territory of Ukraine controlled by Nestor Makhno (1888-1934) with its center in the town of Huliai-Pole in today's Zaporizhzhia region (1918-1921) was another attempt of Ukrainians to create their own state. Finally, almost all big villages or groups of villages in the territory of so-called Great Ukraine or Dnieper Ukraine (without Galicia, Western Volyn, Transcarpathia and Bukovyna) created their independent republics, too. 
The Cold Ravine (Kholodnyi Yar) Republic (1919-1922) with its center in Melnyky village became the most famous of them. Amazing illustrations of firmness were shown by the Medvyn Republic (1920-1921), which included only two villages: Medvyn and Isaiky. Almost every region of Ukraine had its military leaders, or otamans, each of whom was doing his best and fighting for an independent Ukraine. In the Transcarpathia region, in 1919, the Hutsul Republic with its centre in Yasinia village was created. Of course, all the mentioned examples cannot claim to be regarded as genuine states. They are evidence of the great scope and energy of the Ukrainian revolution. They also indicate that state formation was not a common project of Ukrainians. That is why it will be more appropriate to use the plural: the age of the Liberation Struggle included many different Ukrainian revolutions, which was, consequently, the reason for their defeat.

The thing is that each of them understood the final goal of struggle differently and rather unclearly. The list of the main objectives might look like the following: liberty, justice, property, and, finally, an independent Ukrainian state as a base demand. Here we have in regard the socalled unwritten or folkloric tradition, which was rather distant from the modern ideological demands presented in the times of the Liberation Struggle by a narrow circle of the political elite. What is most important for Ukrainians is a revolt against injustice itself, as a process. The format and rhetoric of struggle almost always appealed to Cossack times (its history most likely begins

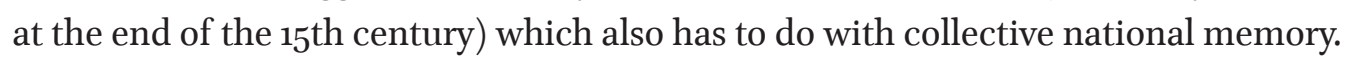

\section{Between East and West}

Let us speculatively claim that the strength of contemporary civil society is rooted in Ukrainian traditions of borderlands military culture between East and West, on the Wild Field's edge. Although Ukraine was organically both the West (the Kyiv-Mohyla Academy phenomenon) and the East, as the Wild Field (which is part of Southern and South-Eastern Ukraine today) and was under Islam influence (the Crimean Tatars and Turks), it was sufficiently developed militarily, economically, and culturally by Ukrainian Cossacks. Ultimately, in the times of the Cossack state, Bohdan Khmelnytskyi's "Zaporizhzhian Army" (Viisko Zaporozke) and, later, Ukrainians were pulled into ongoing wars against the Crimean Khanate, Poland, Turkey, and Russia. Almost all military actions had an important social implication.

The National liberation struggle in Ukraine has always been correlated with social emancipation. In the national memory, it is imprinted in the same terms as upholding liberty, justice and property, although being based on the early modern sense of these words at that time. Since those times, which also concur with the flourishing of Ukrainian baroque culture, myths about the Golden Age of Ukrainian history have been formed. These myths are linked to the idea that every Ukrainian is personally a free individual and together Ukrainians make up the Cossack nation. This collective belief has occupied a special place in the system of national culture.

For example, my grandmother, who came from Lykhvari, a small Cossack village in the Reshetylivka district of Poltava region, explained to me, a primary school student in the mid-197os, that I am a free person because I am of Cossack origin. We need to notice that her concept was not only romantic, but legalistic as well. She said, "Remember, no-one in your family was ever a serf." So, it matters that my right to be a free person was defended and affirmed by centuries of Ukrainian history and that this is the basis for my life in the future. These "natural" Ukrainian 
rights cannot be questioned: if something wrong is happening now, it will be corrected and arranged in the future.

Ukrainians have always been collectively expecting a successful and final rebellion, postponed in time, when justice will be exercised on every account. The absence of modern and timely political demands sometimes led to odious murderous attempts to restore justice, as during the times of the Koliyivshchyna revolt (1768-1769). Similar traditions, connected to "Golden" Cossack times, later had various realizations in different modern political cultures. Thus, my father, born in Pomoriany, a town in today's Lviv region, recounted what he had heard from his relatives and neighbours about a confrontation of two different political cultures of one ethnicity in the time of World War I, just before the Liberation Struggle.

In 1916, the Russian army advanced to the territory of Galicia. A cavalry unit, which consisted of Kuban Cossacks, was quartered in Pomoriany. These were ethnic Ukrainians who did not speak Russian at all, sang the same songs as Galician people, were chunky, and had large papakhas, specific Kuban sabres, and a golden earring in one ear. Pomorianians could see that these people were Ukrainians, but did they look like Bohdan Khmelnytskyi's Cossack army that had also crossed into Galicia some time earlier? The Ukrainian community had also saved heroic memories about those times because two hundred locals joined Khmelnytskyi in the 17th century. And as the stories said, my relatives were among them, too.

For some reason, Kubanians did not look the way Galicians wanted them to look every morning they fell into a column, took off their papakhas, and raising a Russian flag, sang "God, save the tsar!" But "true" Ukrainian Cossacks were supposed to serve the people, not the authorities, not to mention the occupying authorities. Furthermore, Pomorianians were struck by the cunning anti-Semitism of the Kubanians, who could stop a group of Jews in the street and, laughing out loud, drive them to a water hole, as if they were a herd - all this to get some money from them, which would end the "joke." This stress for locals repeated itself only during World War II when two Germans from the field gendarmerie shot down two small Jewish girls in the street in full daylight. That is why Pomorianians would constantly doubt whether the Kubanians were "our people."

A solution to the problem came up by itself. The Kuban unit moved on, got itself into an Austrian ambush, all of its soldiers perishing. A fireman picked up their papakhas and brought them to Pomoriany. Local Ukrainians solemnly buried those papakhas instead of the soldiers and decided that they were "theirs," Ukrainians, yet wild and destroyed by the tsar's power. So, in the context of one Ukrainian ethnic culture, two political cultures came into collision: one was from the area of Austro-Hungarian Galicia and the other was from the Kuban, fully incorporated by Russia.

\section{The Ukrainian Revolution}

Coming back to the times of the Liberation Struggle, let us notice that it was an even more tragic collision of orientations, not only political cultures. The Democratic February Revolution of 1917 in St. Petersburg started with the uprising of a Ukrainian Volyn regiment in the Russian army, going out into the streets under Ukrainian blue and yellow flags. The all-Russian revolution grew 
into national revolutions of the empire's "outskirts," including the same-year announcement of the above-mentioned independent Ukrainian People's Republic with a progressive socialistic government, as well as of the truly Ukrainian Kuban People's Republic (1918-1920); the activation of independence movements in other territories of the Russian Empire, which were previously colonized by ethnic Ukrainians (specifically, by the so-called Siryi Klyn in Middle Asia and Zelenyi Klyn in the Far East).

However, this enormous energy was differently-vectored and divided by political party features. Thus, Ukrainian socialists, who held the majority, refused to collaborate with Hetman Pavlo Skoropadskyi (1873-1945), seeing him as a reactionary monarchist. Anarchist Nestor Makhno, who must have been one of the most charismatic Ukrainian military leaders of that time, was ironic about state intentions among the socialist guides of the Ukrainian People's Republic, first concluding treaties with them, and then with Russian Bolsheviks that were also "not strangers" to him (at one time of his life he had shared tsarist prisons with them). Partisan chieftains (otamans) of numerous village republics were most frequently fighting against everyone, confining themselves to their local territories. Brilliant Kuban Commander in Chief Andrii Shkura (Shkuro, 1886-1947) became a stalwart supporter of General Denikin, Commander in Chief of the Volunteer Russian Army, and was keen on restoring the "one and indivisible" Russian Empire.

At the same time, we can list examples of the uniting of state formation powers. Unfortunately, all of them were mostly symbolic. On January 22, 1919, the Ukrainian and the Western Ukrainian People's Republics united, and the day before the All-National Assembly in Khust resolved to add Transcarpathia to the Ukrainian People's Republic. A similar Bukovynian assembly took place in Chernivtsi on the 3 rd of November, 1918. However, actual political and military disintegration of the Ukrainian powers finally led to the defeat of the young state, which left only positive precedents of democratic intentions after itself. The problem was that nobody valued those achievements. Ukraine was now occupied by new Russian imperialists, the Bolsheviks, who would organize the Holodomor (1932-1933) ten years later. Major international players, demoralized by the success of the Bolsheviks, hardly noticed the emergence of a new state with the unknown name "Ukraine" on the political map of Europe.

\section{Concept of National Interests}

All Ukrainian non-Soviet sources aimed at gaining a deeper understanding and documenting the described events: they continued the unfinished business of state formation. In other words, they had a distinct journalistic strain. First of all, let us consider the completion of the formation of the Ukrainian political identity. Thus, academic and essayistic works of leading Ukrainian intellectuals — Mykhailo Hrushevskyi (1866-1934), a historian; Volodymyr Vynnychenko (18801951), a writer; Serhii Yefremov (1876-1939), a literary critic; Symon Petliura (1879-1926), a theatre critic; hetman Pavlo Skoropadskyi, a professional military man; Dmytro Dontsov (1883-1973), a journalist and an essayist; as well as historians Dmytro Doroshenko (1882-1951) and Viacheslav Lypynskyi (1882-1931) — had clear ideological and evidential differences. All these authors played important roles in the Ukrainian liberation movement. 
The main conclusion made by the political leaders who continued the struggle for the state independence of Ukraine after the defeat of the Liberation Struggle was made in favor of uniting around the national interests of Ukraine. This political concept was suggested by Dmytro Dontsov, an ideologist of Ukrainian nationalism. He had a huge impact on the formation of a new generation of leaders connected with the Organization of Ukrainian Nationalists, founded in 1929, and the Ukrainian Insurgent Army created in 1942. Dontsov was absolutely critical of the leaders of the Ukrainian People's Republic who were associated with the Liberation Struggle.

Appealing to the fate of the whole nation, he rejected party affiliation. His ideology concentrated on a Ukrainian revolution as an armed struggle for the creation of an independent Ukraine. At the front, there is no place for the categories of democracy or authoritarianism because an army must have a common strategy to win. However, in his views of the state as such, Dontsov was oriented on the American and British models. This fact makes present ideologized interpretations much more difficult for representatives of the neo-Soviet historical school who have built their academic careers on anti-Ukrainian activities or are ideological fanatics.

Actually, looking at Ukrainian military victories from a detached humanistic point of view, we are able to divide the reasons for the main bloody battles into four groups: examples of motivated struggle for state independence; for social emancipation; sorting out relationships with national minorities, which denied the Ukrainian right of statehood and supported colonial metropolitan countries; and the retardation of the modern forms of political culture due to the formation of political discourse mainly based on traditional patriarchal categories of "our own" and "the other." The worst of it is that all these factors often became entangled. However, when Ukrainians were able to return to the restoration of their state, they always proposed coalitions and democratic models. In the 2oth century, such were all the mentioned forms of the age of the Liberation Struggle, as well as Carpathian Ukraine with its capital in Khust (1939), the Ukrainian State Government in Lviv (1941), and the State of Ukraine (1991).

The positive political capital of the age of the Liberation Struggle, connected with aspirations to have a democratic state governed by the rule of law, was somewhat actualized in the first years of a colonial body called the "Ukrainian Soviet Socialist Republic" (1919-1991). Before Russian communists occupied Kyiv in 1921, the head of the Ukrainian Central Council (the parliament of the age of the Liberation Struggle (1917-1918)), Mykhailo Hrushevskyi, even returned from emigration. Later, Ukrainian dissidents (1950s-1991) and nationalists (thinking that "social emancipation can happen only together with national emancipation") also paid attention to the ideas of social justice. The ideological political heritage of the Ukrainian People's Republic became especially relevant again when Ukrainian statehood was renewed after the collapse of the Soviet Union.

Specific attention should be paid to the history of Ukrainian socialism which, contrary to imperial Russian socialism, had a national liberation and anticolonial nature. From this perspective, Edward Said's work Orientalism (1978) is also about Ukraine as a former colony.

Under occupation conditions, the Ukrainian nation existed with an incomplete social structure, mainly formed by the peasantry. When a famous Ukrainian intellectual, Mykhailo Drahomanov (1841-1895), was reflecting on ideas which could appeal to the vast majority of Ukrainians, he came to the conclusion that these could be socialist ideas. Thus, in Ukraine, 
after the Cossack state, in modern times, the programmes of social and national liberation were again combined. At the beginning of the 2oth century, almost all politically active Ukrainian intellectuals, except for some landlords and the wealthy who had Ukrainian cultural sentiments, related themselves to the socialist movement. Meanwhile, in the all-Russian context, Mykhailo Drahomanov happened to disseminate the ideas of liberalism and constitutionalism.

Another merit of Mykhailo Drahomanov is also the impact he made on the most influential representative of Ukrainian intellectual history, Ivan Franko (1856-1916), who first turned to the Ukrainian socialist movement from his Moscowphile orientation. Later, in his article called "Beyond what is possible," in response to an epochal work by Mykola Mikhnovskyi (1873-1924) Independent Ukraine (1900), Franko also turned from Marxism to the principles of Ukrainian nationalism. Before its publication in Lviv, this was a speech the author made first in Poltava and then in Kharkiv. Mikhnovskyi was the most mysterious figure within the Liberation Struggle and, in his turn, influenced the world-view of Dmytro Dontsov. He was "right-wing," paid attention to the military independence movement, and worked with Dontsov in Hetman Skoropadskyi's government.

After the defeat of the Liberation Struggle, ideological fashion gradually turned from a left-wing to a right-wing orientation of the majority of active politicians and consolidates, with the start of World War II. We often deal with the substitution of ideas because the ideas of social justice associated with Marxism, first of all, were never alien to the Ukrainian peasant nationalistic movement. Nationalists expressed their opinion within Dontsov's doctrine of the protection of national interests, aimed at the creation of the Ukrainian Independent United State, which is why they were considered to be exclusively "right-wing." Within the framework of the Soviet Union, the nationalist label was applied not only to true representatives of the organized opposition of the same name, but also to dissidents, independently thinking Ukrainian intellectuals, and, later, even to those who were using the Ukrainian language as a matter of principle.

Since only nationalists organized armed resistance against occupants (Nazi Germans, Soviet Russians), and against the authorities of neighboring countries, none of which recognized the right of Ukrainians to fight against colonial dependency. The nationalist resistance included various party elements including former national democrats (Nil Khasevych, an artist, 1905-1952) and Marxists (Mykhailo Stepaniak, a former member of the Communist Party of Western Ukraine, consequently a member of the leadership of the Organization of Ukrainian Nationalists (OUN), and a soldier of the Ukrainian Insurgent Army (UPA), 1905-1967). The Ukrainian Insurgent Army became a broad liberation movement representing different national minorities of interwar Poland and the Soviet Union. It was dominated by a concept embodied in the formula of the icon of Ukrainian intellectual history, Taras Shevchenko (1814-1861), who expressed his opinion of Russia as "a prison of nations," and whose main motto was: "Liberty to nations, liberty to a person."

Today, the Ukrainian class of politicians again faces the task of creating a full political spectrum, represented by ideological right-wing, left-wing, and liberal parties. The distance between the state and society has to be overcome in the Ukrainian political vocabulary. Still not solved is the problem of the pro-Communist, pro-Russian and pro-Putin orientations of political powers represented by the left wing. Instead new leftists, who are ideologically linked to relevant neo-Marxist movements of the Western world, formed no organized political power. Yet they 
continue to ignore the post-colonial state of Ukrainian society. Quite traditionally (following the Liberation Struggle), they contrast the state with different social values, seeing no value in the state itself, which enables the existence of a free society.

\section{New Ukrainian Revolutions}

Usually, four revolutions connected with independent Ukraine are considered. These are the students' Revolution on Granite (1990), the all-Ukrainian "Ukraine without Kuchma” protest (2000), the Orange Revolution (2004-2005), and the Revolution of Dignity (2013-2014). All of them were associated with the gradual development of political culture in Ukrainian society. The gap between modern and traditionally mythological Ukrainian discourses has become much smaller. Indeed, the most ideologically advanced Revolution of Dignity "naturally," rather than conceptually, absorbed some historical myths and tied them to new networking technologies.

The Revolution on Granite was in tune with the explosive dissemination of printed selfpublished works (samrydav). The Orange Revolution, as Timothy Garton Ash said in his speech at the Kyiv-Mohyla Academy, became a "TV revolution," when a television picture helped to propose that "Together we are many, no one can defeat us" ("Razom nas bahato, nas ne podolaty"). The success of the Revolution of Dignity is connected with social networks, inclusion into global processes, and the development of Ukrainian civil society. It should be mentioned that historically the Euromaidan concurred with the crisis of values of the West facing new global challenges. What is most dangerous is the hybrid renewed Russian "empire of evil" with its fake reality. For many centuries, it has been opposed by Ukrainian liberation discourse with all its aspirations of liberty and justice.

It turned out as if Ukrainians were always ready to live in field conditions, to build a Sich settlement (a Cossack archetype) in Kyiv's centre, to solve important civil issues at the Maidan (at a viche, a popular assembly inherited since the times of Kyivan Rus), to create independent media and social networks, to arm, to provide treatment, to teach people, to rise to defend barricades driven by the bells of St. Michael's Golden Domed (Zolotoverkhyi) Monastery (which gave shelter to Kyivans during the attack of the Mongolian army in the 12th century), to create numerous volunteer organizations, to revive the high morale of the Ukrainian army, and later to stop attacks of the Russian army. There was no single centre which commanded or performed strategy planning. However, everyone knew his own place and cooperated with other members of the Revolution. The centralized coordination of actions was not the same as the rule of one. On the contrary, the power of resistance was in a decentralized network and the self-sufficiency of its separate elements.

The Revolution of Dignity has compensated the old collective anxiety which was due to a lack of leadership and unity. Leadership has finally become a team concept, rather than solely an expression of some leaders' charisma. The Maidan symbolized unity and demands, regardless of political, national, religious or any social affiliation. Everyone just had to make their contribution to the victory. This was a celebration not only of civil society, but also of the Ukrainian political nation, the first time in history when all national minorities rose to defend the Ukrainian state as 
their own. Accordingly, old myths and offences, accumulated by centuries of wars and collisions, vanished from the collective mind.

After the Revolution of Dignity, the Ukrainian liberation movement stopped being an alternative. Post-revolutionary government has already stopped being perceived as occupational. Strict demands of Ukrainians to the government, in spite of some efforts to continue cultivating hostility, have developed into activity through the development of civil society. However, we are still far from the total destruction of differences between society and state. The Ukrainian government does not yet enjoy sufficient trust because of corruption.

\section{Conclusions}

Only the burning down of something and ruination can be quickly accomplished. Building new social relationships, disseminating new governing practices, and creating an effective state require more time. Yet, Ukrainians are not ready to delegate all responsibility for the protection of national interests to the state: when we hear about a person with a Molotov cocktail, we will call him or her an activist; during the Revolution of Dignity and the war with Russia, Ukrainians took up arms; they want to maintain the specific status of volunteer battalions, valuing personal courage more than relying on the system of the Military Forces.

After the victory of the Revolution of Dignity, contemporary generations should draw attention to the experience of the Liberation Struggle with all of their successes and fatal failures. Now, like a hundred years ago, Ukrainians need to create not an alternative movement, not a partisan detachment, and not to take vengeance for injustice. It is about building a modern effective state to which all citizens can delegate their certain rights and responsibilities, hoping for its resolve in protecting national interests and for its effective professionalism. The transition from timeless mythological and stereotypic existence to the real-time life of the nation requires switching attention from a revolutionary process to concrete goals and consequences of the struggle.

Serhiy Kvit is a professor at the Kyiv-Mohyla School of Journalism. He was President of the National University of Kyiv-Mohyla Academy from 2007 to 2014, and the Minister of Education and Science of Ukraine from 2014 to 2016. His research focuses on educational reforms, mass communications, and philosophical hermeneutics. He has held a Fulbright scholarship at Ohio University, a Kennan Institute scholarship at the Woodrow Wilson International Centre in Washington DC, and a DAAD (German Academic Exchange Service) scholarship at the University of Cologne. 